Review Article

\title{
A role of radioprotective agents in cancer therapeutics: a review
}

\author{
Nagalaxmi Velpula, Sridevi Ugrappa*, Srikanth Kodangal
}

\begin{abstract}
Department of Oral Medicine and Radiology, Sri Sai College Of Dental Surgery, Vikarabad, Andhra Pradesh, India
\end{abstract}

Received: 23 August 2013 Accepted: 3 September 2013

\section{*Correspondence to: \\ Dr. Sridevi Ugrappa, \\ Email: \\ srideviugrappa@gmail.com}

(C) 2013 Velpula $\mathrm{N}$ et al. This is an open-access article distributed under the terms of the Creative Commons Attribution Non-Commercial License, which permits unrestricted non-commercial use, distribution, and reproduction in any medium, provided the original work is properly cited.

\begin{abstract}
In the field of medicine or dentistry, cancer is one of the most common causes for death of the individual worldwide, in which oral cancer accounts for about $10 \%$ of it. One of the most important treatment modalities for cancer includes radiotherapy. During radiotherapy, exposure of the normal tissue to these ionizing radiations, results in mutagenesis and cell death. Several modalities and clinical approaches have been made to reduce these early and late complications of the radiotherapies and one among them is, by the means of pharmacological agents. Many experimental and clinical studies have given rise to new concepts of chemical and molecular pharmacological agents that could be effective in protection and treatment of radiation damage to surrounding normal tissues.
\end{abstract}

Clinical Significance: To reduce the significant complications in irradiated patients, the clinical implication of these radioprotective agents have emerged as potential drugs and with anti-tumour effect in the radiotherapy of various cancers including oral carcinomas.

Keywords: Chemical modifiers, Radioprotectors, Radiation damage

\section{INTRODUCTION}

Radioprotective agents have been used to prevent damage to the tissues from the radiations that have been produced while diagnostic and treatment phases of carcinomas. As, oral cancer is one of the most prevalent cancers and is one of the 10 most common causes of mortality, it accounts for about $2 \%$ in male and $1 \%$ in female death due to oral cancer. ${ }^{1}$ Over $40 \%$ of cancer patients will require radiotherapy during their management, at some time or other, either for curative or palliative purpose. ${ }^{2}$ The type of radiations used in cancer treatment are called ionizing radiation. These ionizing radiation produces free radicals in cell by a process of radiolysis of water. As these free radicals interact with cellular macro and micro-molecules which leads to cell dysfunction and mortality in tumour cells as well as normal cells. ${ }^{3}$

The tumor cells proliferate very rapidly, and cause, a central necrotic and hypoxic region which is a radioresistant area. To overcome this problem, higher doses of radiation must be delivered to control the tumor, which in- turn leads to more toxic effect on surrounding well perfused vascularised normal tissues. This necessitates the protection of normal cells surrounding the tumor from radiation injury.

Various efforts to reduce the toxicity from radiation injuries have been made both by non-pharmacological intervention or technological improvement in radiation delivery system and by pharmacological modifiers, called as radioprotective agents.

In 1942, Dale introduced the terms radioprotection and radioprotective agents and also carried out many studies using enzymes as indicative molecules. However, in 1949, Patt and his co-workers were the first to investigate the radioprotective effect of amino-acid cysteine when exposed to lethal doses of X-rays. ${ }^{5}$ The most significant contribution of the Walter Reed Army Institute of Research (WRAIR) initiatives the development of WR2721, S-2-(3-aminopropylamino) ethylphosphorothioic acid, and many related phosphorothioates, which were first synthesized by Akerfeldt in 1959 as radioprotective agents. 


\section{RADIATION INJURY AND TISSUE DAMAGE}

Ionizing radiation which causes genetic mutation or cell death can be divided into photon radiation (X- rays and Gamma rays) and particulate radiation (electrons, protons, neutrons, alpha $(\alpha)$ and beta $(\beta)$ particles). Some types of ionizing radiation have more energy (high-energy photons are emitted from radioactive substances such as cobalt, cesium, iridium) than other (electron beam produced by linear accelerator) and henceforth have more penetrating power into the tissue. Radiation oncologists select the type and energy of radiation that is most suitable for the particular cancer patient. ${ }^{3}$

Ionizing radiation exerts its effect through the production of free radicals that destroys DNA and structures such as cell membrane of the target cell. ${ }^{4,5}$ Following whole body exposure to moderate doses (2-5Gy), damage to the hematopoietic cells is the major cause of morbidity, while at higher doses (5-10Gy), damage to the gastrointestinal tract, lung and brain also contributes to the total effect. ${ }^{6,7}$ Although in these cases death is rare, but late effects of radiation sequel may severely compromise the quality of life of cancer survivors. ${ }^{4}$

Complications of head and neck radiotherapy include oral mucositis, taste alterations which generally subside within several weeks after completion of treatment, but some late effects like damage to salivary glands with resultant xerostomia (irradiation exceed more than 35Gy), damage to the dentition, muscular fibrosis, osteoradionecrosis, cartilage necrosis, dysphagia and damage to the eye, ear and central nervous system are also seen. 3,8

Effects of radiation at the molecular level of cell can be classified as given by M I Koukourakis et al. ${ }^{4}$

- Type I early radiation effects/ cellular depletion

- Type II early radiation effects/ reactive gene activation

- Type III late radiation effects/ tissue disorganisation

- Type IV radiation effects/ stochastic effects

- Type $\mathrm{V}$ radiation effects/ bystander effects.

To overcome these complications, some efforts have been made which includes:

\section{Technical or non-pharmacological improvement by means of}

- External beam radiotherapy (Intensity modulated radiation therapy - IMRT, image guided radiotherapy - IGRT)

- Stereotactic radio-surgeries.

- Radioisotope bound to monoclonal antibody for tumor targeted radiotherapy (Radioimmunotherapy).
Pharmacological intervention by use of radiation modifiers/protectors

An ideal radioprotector should have the following criteria and abilities functionally: ${ }^{9,10}$

- Free radical scavenging.

- Radio oxidative damage.

- Selective in protecting normal tissues from radiotherapy without protecting tumor tissue.

- Absence of cumulative effect in repeated administration.

- Should have an efficacy for different types of radiation (X-rays, gamma, neutrons).

- Immunomodulation action.

- Facilitate repair of damaged and affected organs.

\section{CLASSIFICATION OF RADIOPROTECTIVE AGENTS}

Radioprotective agents may be classified as follows:

- Based on time of radiation ${ }^{11,12}$

$>$ Chemical protectors or Prophylactic agents

$>$ Mitigators

$>$ Treatment or Therapeutic agents

- According to their mechanism of action (MOA) $(\text { Table-1 })^{13-16}$

- According to their mechanistic biological activity (Table-2) ${ }^{17-19}$

\section{MECHANISM OF RADIATION PROTECTION ${ }^{20-24}$}

Different theories that have been propounded that include:

- Radical scavenging.

- Hydrogen donation.

- Mixed disulphide formation.

- Release of endogenous radioprotectors like glutathione, superoxide dismutase.

- By inducing hypoxia in the tissues.

- DNA repair and recovery process.

It is also well known that radioprotective activity is accomplished through different mechanisms on three special levels of cell organization, i.e. at molecular level, physiological-biochemical level and at organic level. ${ }^{25}$

The mechanism of free radical scavenger suggests that certain agents are oxidized by free radicals, therefore forming stable compounds and incapable of reacting with other cellular components. This mechanism prevents the free radicals from reacting with the cell vital components. 
Table 1: Classification according to their mechanism of action (MOA).

\begin{tabular}{|c|c|c|}
\hline Compounds & Mechanism of action & Examples \\
\hline Sulfhydryl compounds & $\begin{array}{l}\text { Free-radical scavenging, } \\
\text { donation of } \mathrm{H} \text { atom. }\end{array}$ & $\begin{array}{l}\text { Cysteine, Cysteamine, } \\
\text { Glutathione,amino-ethyl sothiourea } \\
\text { (AET), Amifostine (WR 2127) and } \\
\text { other WR-compounds. }\end{array}$ \\
\hline Antioxidants & Free-radical scavenging. & $\begin{array}{l}\text { Tempace, Vitamin A, E, \& C, } \\
\text { Tocopherol-monoglucoside (TMG), } \\
\text { Melatonin, etc. }\end{array}$ \\
\hline $\begin{array}{l}\text { ACE inhibitors (Angiotensin } \\
\text { Converting Enzymes) }\end{array}$ & $\begin{array}{l}\text { Protease inhibition (through renin- } \\
\text { angiotensin system), anti-oxidation, } \\
\text { collagen synthesis inhibition, anti-fibrotic } \\
\text { and anti-inflammatory action. }\end{array}$ & $\begin{array}{l}\text { Captopril, Enalapril, Pencillamine, } \\
\text { Pentoxyfylline, L-158, 809, etc }\end{array}$ \\
\hline Metalloelements & Metallothionine induction & $\begin{array}{l}\text { Manganese chloride, Cadmium salts, } \\
\text { Bismuth Subnitrate, etc. }\end{array}$ \\
\hline Immunomodulators & $\begin{array}{l}\text { Immune stimulation, increased production } \\
\text { of cytokines }\end{array}$ & $\begin{array}{l}\text { Gamma-interferon, Polysaccharides } \\
\text { AM5, AM218, Broncho-Vaxom, } \\
\text { Trehalose dicorynomycolate, } \\
\text { Ammonium trichloro- telluride } \\
\text { (AS101). }\end{array}$ \\
\hline $\begin{array}{l}\text { Plant extracts and isolated } \\
\text { compounds }\end{array}$ & $\begin{array}{l}\text { Free-radical scavenging, anti- } \\
\text { oxidation, anti-inflammatory action. }\end{array}$ & Curcmin, Orientin, Vicinin, Mint \\
\hline DNA binding ligands & Electron transfer, free-radical scavenging & Hoechst 33342 \\
\hline Other Compounds & $\begin{array}{l}\text { Free-radical-scavenging Antioxidant, Anti- } \\
\text { inflammatory action. }\end{array}$ & $\begin{array}{l}\text { Melatonin, Carnosin, Tempace, } \\
\text { Tempol, Honey bee venom }\end{array}$ \\
\hline
\end{tabular}

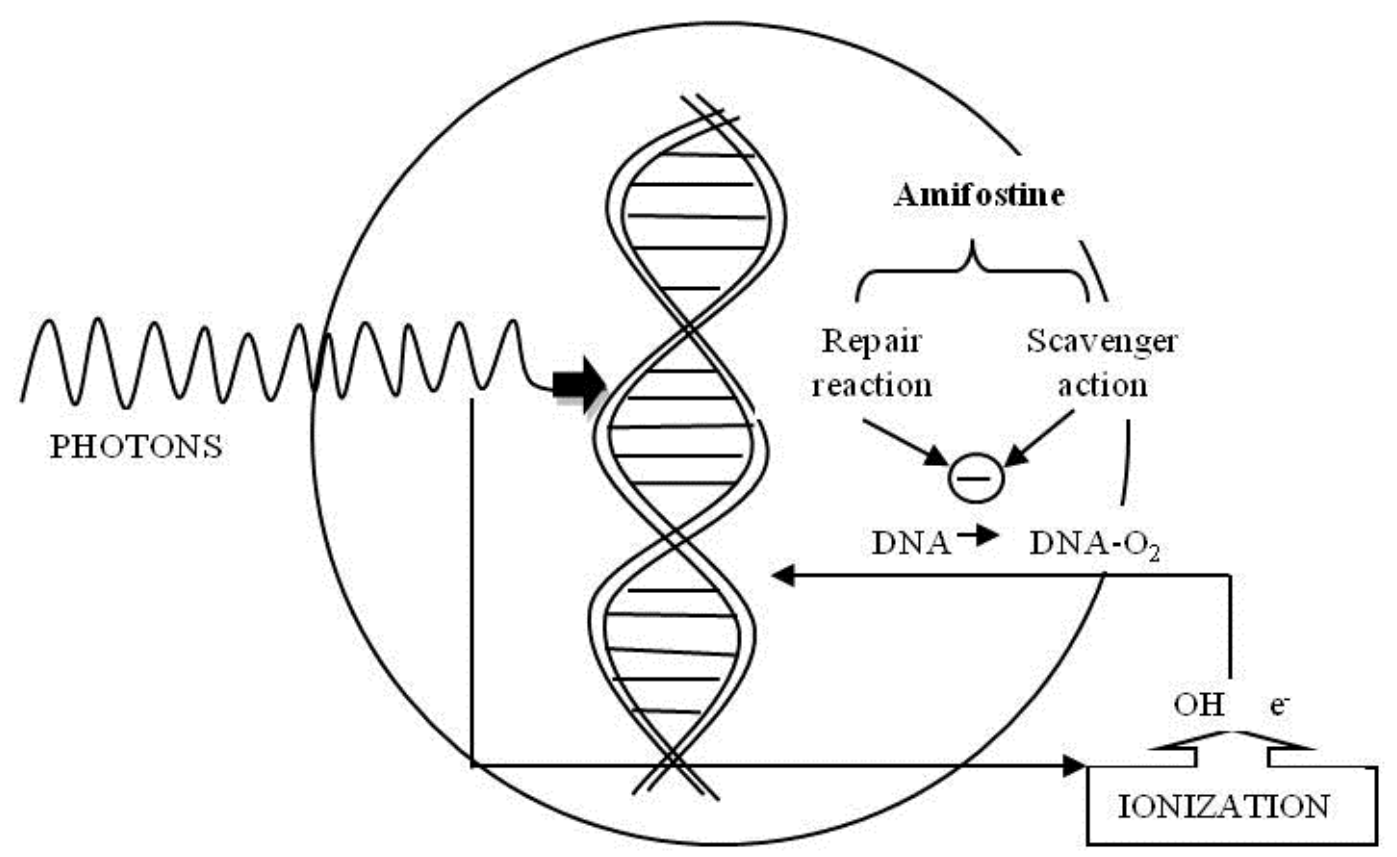

Figure 1: Mechanism of dual action of Amifostine in tumour cell. 
Table 2: Classification according to their mechanistic biological activity.

\section{A. Protectants against all types of radiation effects}

1. Blockers of oxygen consumption

2. Free radical scavengers (endogenous and exogenous)

3. DNA repair boosters
E.g.: Hydroxytryptamine, Amifostine, Cobaltchloride, Desferoxamine, Okadaic acid

E.g.: Superoxidismutases, Glutathione, N-acetyl-cystein, Amifostine (WR-1065) Fullerenols

E.g.: Amifostine (WR-33278), Resveratrol, Vectors with repair enzymes

\section{B. Protectants against Type I early radiation damage}

1. Death pathway modulators

E.g.: Sodium orthovanadate, Angiotensin receptor blockers, Flagellin analogues (Toll-like receptor ligands).

2. Growth factor

E.g.: Hemopoietin growth factors, Keratinocyte growth factor, Becaplermin (rhPDGF-BB), Telbermin (rhVEGF)

\section{Protectants against Type II early and Type III late radiation effects}

1. Blockers of radiation inflammation and chemotaxis

E.g.: IL-10 inducers, Infliximab (anti-TNFa), Tolcizumab, IL-6 blockers

2. Blockers of autocrine/paracrine pathways

E.g.: VEGF blockers, Infliximab (antiTNFA Ab), HGF gene transfer, Retinoic acid, ACE inhibitors, COX inhibitors

\section{Protectants against Type IV stochastic effects:} Antimutagenic keepers of genomic integrity

\section{E. Protectants against Type V bystander effects}

E.g.: Amifostine, Avotermin (TGFb), Macrophage activation suppressors

E.g.: Amifostine, NOS-inhibitors, Macrophage activation inhibitors, Demethylation targeting agents
Another mechanism which has been demonstrated with polymers is the repair by hydrogen donation. If a $\mathrm{R}-\mathrm{H}$ molecule is converted into a $\mathrm{R}$ (radical $\mathrm{R}$ ) by exposure to radiation, a protective agent can donate a hydrogen atom to this radical, restoring it to its original state.

The formation of mixed disulfides is a mechanism proposed for aminothiols and involves radioprotector binding to cellular components. Sulfhydryl compounds of the aminothiols form mixed disulfides with sulfhydryl compounds of cellular proteins. When one of these disulfides is attacked by free radicals, one of the sulfur atoms is reduced and the other is oxidized. If the sulfur atom of the protein is reduced and the sulfur atom of the protective agent is oxidized, the protein is not damaged. Binding of aminothiols and disulfides to DNA has been considered a potentially important factor in radioprotection.

In view of these considerations, Brown ${ }^{22}$ proposed that the sulfhydryl compounds of the radioprotective aminothiols act by binding to DNA, and thereby, reversibly inhibit replication and stabilize their structure, which provides additional time for repair. Oxidation of the thiols consumes enough oxygen to reduce its tension, and it has already been demonstrated that hypoxia is radioprotective.
Also another mechanism behind this sulfyhydryl compounds of amiothiols in protecting normal tissues but not tumour cell is poor drug penetration due to poor blood perfusion in tumour cells and also presence of higher $\mathrm{pH}$ and alkaline phosphatase enzyme in normal tissue but not in tumour tissues (Figure 1). ${ }^{26}$

Biological activity of cytokines like interleukin-1 (IL-1), tumor necrosis factor alpha (TNF- $\alpha)$, granulocyte colonystimulating factor (G-CSF) and granulocyte-macrophage colony stimulating factor (GM-CSF) act as radioprotective agents by stimulating the stem cells and hematopoiesis.

Immunomodulators are another class of radioprotectors that can enhance the proportion of hematopoietic stem cells into more radio-resistant phase of the cell cycle or increase of the size of the post-irradiation stem cell population. ${ }^{27,28}$

Various studies and clinical trials have been done regarding the protective efficacy of various compounds like L-Carnitine which prevents the formation of free radicals by xanthine-xanthine oxidase system, ${ }^{29}$ Palifermin-recombinant human keratinocyte growth factors, ${ }^{30}$ herbal products like black seed (Nigella Sativa oil), ${ }^{31}$ multiple ex-vivo studies conclude that the suppression of bone marrow hematopoietic activity post radiation therapy is mitigated significantly with 
ON0121.Na, ${ }^{32}$ wheat germ-oil etc., ${ }^{33}$ but Amifostine (WR1065) remains one of the most promising drug in clinical use presently because of its dual action nature as a free radical scavenger and in repair reaction of DNA damage $^{26}$ and is safe and practical to administer in a clinical setting.

\section{TRANSPORT OF RADIOPROTECTORS THROUGH BIO-MEMBRANES ${ }^{34}$}

This can happen by diverse mechanisms:

- Lipophilic substances by passive diffusion or passive transport (carrier) without energy, i.e. ATP consumption.

- Hydrophilic compounds by passive transport (e.g. ion channels) or active transport (ATP-consuming transport).

- By vesicular transport as by phagocytosis, pinocytosis.

- By receptor-mediated endocytosis.

With the use of radioprotective agents in cancer therapy, normal tissues are protected but not the cancer tissues because of some specific transport process.

For example, Amifostine (WR-2721) and its derivatives are phosphoaminothionate and these pro-drugs are dephosphorylated by alkaline phosphatase enzyme. Dephosphorylated metabolites diffuse passively through the cell membrane and are oxidized in the cell. These compounds reveal chemical similarity to some other compounds in the cell and henceforth are also transported by the some special transporter leading to cellular accumulation of amifostine derivatives. ${ }^{35}$ Different transport systems are necessary for the tissue distribution of these radioprotectors.

\section{CONCLUSION}

Radiation therapy is frequently used in the definitive management and palliative care for cancer patients. Treatment of tumor tissue inevitably results in the irradiation of surrounding normal tissues. Technological advances may result in lowering the normal tissue exposure, but it is expected that technologic approach will not completely prevent toxicity in irradiated fields. By the use of these chemical modifier or pharmacological agent, toxic effect on normal tissues can be spared in patients treated with radiotherapy or during irradiation which will improve the quality of life. In spite of discovery and clinical trials of various compounds, Amifostine, remains the promising drug currently in clinical use as a radioprotector.

\section{Funding: None \\ Conflict of interest: None declared \\ Ethical approval: Not required}

\section{REFERENCES}

1. Greenberg and Glick. Burket's Oral Medicine. 11th Edition. Hamilton: BC Decker Inc 2008:153-55.

2. Greenberger JS. Radioprotection in vivo 2009; 23:323336.

3. Reddy SP and Haug RH. Oral and Maxillofacial Surgery Clinics of North America, Oral Cancer 2006;18(4):605-614.

4. Koukourakis MI. Radiation damage and radioprotectants: new concept in the era of molecular medicine. Br. J. Radiol 2012;85(1012):313-30.

5. Nair CKK, Dillip $\mathrm{K}$ et al. Radioprotectors in Radiotherapy. J Radiat. Res 2001;42:21-37.

6. Scholes G. Radiation effects on DNA: The Silvanus Thomson memorial lecture. Br. J. Radiol 1983;56:221-231.

7. Pradhan DS, Nair CKK, Sreenivasan A. Radiation injury repair and sensitization of microorganisms. Proc. Ind. Natl. Sci. Acad 1973;39B:516-530.

8. Dragaric IG and Dragaric ZD. The radiation chemistry of water. Academic Press, New York.1971:256.

9. Upadhyay SN, Dwarakanath BS et al. Chemical Radioprotectors. Defence Science Journal 2005;55(4):403-425.

10. Jalal S. Foundation review: Trends in the development of Radioprotective agents. Drug Discovery Today 2007; 12:794-805

11. Weiss JF, Landauer MR. History and development of radiation-protective agents. Int. J. Radiat. Biol 2009; 7(85):539-573.

12. Citrin D, Cotrim AP, Hyodo F et al. Radioprotectors and Mitigators of Radiation-Induced Normal Tissue Injury. The Oncologist 2010;15:360-371.

13. Maisin, Bacq JR and Alexander. chemical radioprotection : past present and future. Int. J. Radiat. Biol 1998;73:443-450.

14. Kleta R. Cyclophosphamide and mercaptoethanesulfonate therapy for minimal lesion glomerulonephritis. Kidney Int 1999;56: 2312-2313.

15. Khojasteh NH, Zakerinia M, Ramzi H, Haghshenas M. A new regimen of MESNA (2mercaptoethanesulfonate) effectively prevents cyclophosphamide-induced hemorrhagic cystitis in bone marrow transplant recipients. Transplant. Proc 2000;32:596-600.

16. Baliga MS and Suresh Rao. Radioprotective potential of Mint: A brief review. Journal of Cancer and Therapeutics 2010;3(6):255-262.

17. Dumont F, Roux AL and Bischoff P. Radiation countermeasures agents: an update. Expert Opinion.Ther.Patents 2010; 20 (1):73-101.

18. Koukourakis MI, Flordellis CS, et al. Oral administration of recombinant human granulocyte macrophage colony-stimulating factor in the management of radiotherapy-induced esophagitis. Clin Cancer Res 1999;5:3970-6.

19. Kuter DJ. New thrombopoietic growth factors. Clin Lymphoma Myeloma 2009;9:S347-56. 
20. Ainsworth EJ. From endotoxins to newer immunomodulators: survival-promoting effects of microbial polysaccharide complexes in irradiated animals. Pharmacol Ther 1988;39:223-41.

21. Biaglow JE. The effects of ionizing radiation on mammalian cells. In: Farhataziz Rodgers MAJ. Ed. Radiation chemistry: principles and applications. New York: VCH 1987:527-63.

22. Brown PE. Mechanism of action of aminothiol radioprotectors. Nature 1967;213:363-4.

23. Chirigos MA and Patchen ML. Survey of newer biological response modifiers for possible use in radioprotection. Pharmacol Ther 1988;39:243-6.

24. Eastgate J, Moreb J, Nick HS, Suziki K et al. A role for manganese superoxide dismutase in radioprotection of hematopoietic stem cells by interleukin-1. Blood 1993;81:639-46.

25. Livesey JC and Reed DJ. Chemical protection against ionizing radiation. Adv. Radiat. Res 1987;13:285-353.

26. Phillips L, Text book of Radiation Oncology, 2nd edition. pg:54-55.

27. Landauer MR, McChesney DG and Ledney GD. Synthetic trehalose dicorynomycolate (S-TDCM): behavioral effects and radioprotection. J. Radiat. Res 1997; 38:45-54.

28. Kalechman Y, Shani A, Albeck M et al. Induction of acute phase proteins in mice and humans by treatment with AS101, an immunomodulator with radioprotective properties. Immunopharmacology 1995; 29:149-158.
29. Caloglu M, Caloglu VY and Yalta T. Histopathological comparison of L-Carnitine with amifostine for protective efficacy on radiation induced acute small intestinal toxicity. Journal of Cancer Research And Therapeutics 2012;2(8):260-265.

30. Spielberger R, Stiff P, Bensinger $W$ et al. Palifermin for oral mucositis after intensive therapy for hematologic cancers. New England Journal of Medicine 2004;351:2590-2598.

31. Assayed ME. Radioprotective effects of black seed (Nigella sativa) oil against hemopoietic damage and immunosuppression in gamma-irradiated rats. Immunopharmacology and Immunotoxicology 2010;32(2):284-296.

32. Suman S, Maniar M, et al. Administration of $\mathrm{ON}$ 01210.Na after exposure to ionizing radiation protects bone marrow cells by attenuating DNA damage response. Radiation Oncology 2012;7(6):1-9.

33. Barakat IAH, Abbas OA, et al. Evaluation of radio protective effects of wheat germ oil in male rats. Journal of American Science 2011;7(2):664-673.

34. Efferth and Langguth. Transport processes of radiopharmaceuticals and modulators. Radiation Oncology 2011;6(59):1-10.

35. Mitchell JL, Judd GG, Diveley RR, et al. Involvement of the polyamine transport system in cellular uptake of the radioprotectants WR-1065 and WR-33278. Carcinogenesis 1995;16:3063-3068.

doi:10.5455/2319-2003.ijbcp20131203

Cite this article as: Velpula N, Ugrappa S, Kodangal $\mathrm{S}$. A role of radioprotective agents in cancer therapeutics: a review. Int J Basic Clin Pharmacol 2013;2:677-82. 